\title{
Current aspects of Leydig cell function and its regulation
}

\author{
K. M. Tähkä \\ Department of Zoology, Division of Physiology, University of Helsinki, SF-00100 Helsinki 10, \\ Finland
}

\begin{abstract}
Summary. Recent findings on Leydig cell function and its regulation are discussed. Regulatory mechanisms at different organizational levels, i.e. at the level of the pituitary, the testis and the intracellular elements, are briefly reviewed as well as the transmission and the modulation of the hormonal signal at the Leydig cell membrane. Special emphasis is given to local paracrine and autocrine regulatory interactions operating at the level of the testis.
\end{abstract}

\section{Introduction}

Ever since Franz Leydig in 1850 described for the first time the interstitial cells of the mammalian testis there has been a steady increase in information on the function and hormonal regulation of these testicular elements. In 1903, Bouin \& Ancel proposed an endocrine role for the Leydig cell. By the 1930s it was evident that the male hormone was testosterone and that testicular function was under the hormonal control of the pituitary. However, it was not until the early 1960 s that it was conclusively demonstrated that the Leydig cell was the main source of testicular androgens. By the late 1960s and early 1970s the main hormonal interactions between the hypothalamus, pituitary and the testis as well as the principal biosynthetic and metabolic pathways for steroids in the Leydig cell had been delineated (Eik-Nes, 1975). The next decade would witness important new findings concerning the local control of testicular function and the mode of pituitary gonadotrophin secretion as well as the effect of these hormones on their target cells. Perhaps one of the most exciting new topics that has evolved are the paracrine and autocrine regulatory interactions through which the fine tuning of testicular function is achieved. In this article some of the novel findings concerning Leydig cell function and its regulation are briefly discussed. The studies reviewed deal predominately with rodents, the rat in particular. No systematic attempt is made to discuss the comparative aspects of Leydig cell function.

\section{Pituitary control: gland-to-gland communication}

According to current knowledge, gonadotrophins are secreted from the pituitary in pulses of high biological activity (Ellis \& Desjardins, 1982; Kimura \& Kawakami, 1982; Ellis, Desjardins \& Fraser, 1983; Ellis \& Desjardins, 1984b). Changes in reproductive state are usually associated with changes in the amplitude as well as frequency of these secretory pulses (Lincoln, 1981; Karsch et al., 1984; Ellis \& Desjardins, 1984a). Qualitative changes in the chemical composition of LH have also been noted during illness and different developmental stages as well as during pulsatile secretion (Conn, Cooper, McNamara, Rogers \& Shoenhardt, 1980; Reiter, Beitins, Ostrea \& Gutai, 1982; Warner, Dufau \& Santen, 1984).

Considerable inter- and intra-individual variation in the secretory patterns of these hormones seem to exist and so the functional significance of this episodic mode of secretion remains obscure (Ellis \& Desjardins, 1982). However, some relatively recent studies concerning the effect of different 
doses of hCG as well as the effect of different modes of hormone administration on Leydig cell function shed some light on the significance of episodic hormonal signalling. The effect of $\mathrm{LH} / \mathrm{hCG}$ on Leydig cell function in the mature rat is dose-dependent. While small doses of $\mathrm{LH} / \mathrm{hCG}$ increase the number of receptors as well as stimulate testosterone synthesis, large doses have opposite effects (Dufau et al., 1984).

The recovery of the $\mathrm{LH}$ receptors and the steroidogenic elements from the stimulatory and inhibitory effects of $\mathrm{LH} / \mathrm{hCG}$ follow a distinct temporal pattern (Dufau et al., 1984; Huhtaniemi, Warren \& Catt, 1984b). The steroidogenic response of the Leydig cell to a pulse of LH seems to be determined by the pulse amplitude as well as by the previous history of LH pulses to which it has been subjected (Barr \& Pomerantz, 1984).

Despite intensive studies no consensus has emerged on the temporal distribution of LH pulses in normal male rats. In fact, a hormonal profile acquired from one individual during a ' 12 -h' period does not allow reliable predictions to be made concerning subsequent secretory patterns even in the same specimen (Ellis \& Desjardins, 1982). Some of the inconsistencies may be due to discrepancies in blood sampling protocols (Ellis \& Desjardins, 1984b) as well as to failure to measure changes in the ratio of biologically and immunologically active LH that is secreted (Conn et al., 1980; Warner et al., 1984)

\section{Paracrine regulation: intratesticular communication}

Although firm evidence is still lacking, it would seem that a prerequisite for the normal functioning of the spermatogenic cycle is the spatial and temporal coordination of Leydig cell function in accordance to the needs of the spermatogenic phase of the seminiferous tubules (Aoki \& Fawcett, 1978; Parvinen, 1982; Bergh, 1982, 1983; Sharpe, Doogan \& Cooper, 1983; Parvinen, Nikula \& Huhtaniemi, 1984; Syed, Khan \& Ritzen, 1985). If this were the case, peritubular Leydig cells would form a heterogeneous group of cells in which the functional cycles of different cell populations are out of phase with one another (Callard, Pudney, Mak \& Canik, 1985). It is hard to understand how such functional divergence could be achieved through gland-to-gland communication, that is pituitary control alone. Most certainly paracrine regulation, i.e. the reciprocal transfer of information between the Leydig cells and the seminiferous tubules, would also be needed (Wilton \& de Kretser, 1984).

It has been known for some time that androgens are essential for normal Sertoli cell functioning as well as spermatogenesis in mammals (Steinberger, 1971; Ritzen, Hansson \& French, 1981; Sanborn, Wagle \& Steinberger, 1984). Until recently the synthesis of testosterone was considered to be the sole function of Leydig cells. At present, however, it seems evident that the Leydig cell synthesizes other bioactive substances which are mainly involved in the paracrine and autocrine regulation of testicular function. Pro-opiomelanocortin-derived (POMC) peptides have been localized in Leydig cells (Shu-Dong, Phillips, Halmi, Krieger \& Bardin, 1982; Margioris, Liotta, Vaudry, Bardin \& Krieger, 1983). The synthesis of testicular POMC and its cleavage products seem to be under the control of pituitary LH. Specific receptors for $\beta$-endorphin have been detected in Sertoli cells and the paracrine signal seems to be mediated through an adenylate cyclase-dependent mechanism (Dave, Rubinstein \& Eskay, 1985; Fabbri, Tsai-Morris, Luna, Fraioli \& Dufau, 1985). The studies of Bardin et al. (1984) suggest that different POMC-derived peptides have opposing effects on Sertoli cell function. Renin-like activity has also been noted in Leydig cells (Parmentier, Inagami, Pochet \& Desclin, 1983; Pandey, Melner, Parmentier \& Inagami, 1984).

Inverse regulatory interactions seem to exist between Leydig cells and seminiferous tubules. Initially it was believed that oestrogen produced by the Sertoli cells was the regulatory link between the tubules and the Leydig cells (di Zerega \& Sherins, 1981). However, studies with the rat indicated that aromatase activity in Sertoli cells is restricted to the period of immaturity and that the Leydig cell is the main source of testicular oestrogen after sexual maturation (Payne \& Valladares, 1980). 
It was not until recently that significant new information was obtained on the tubular control of testicular function. Rat Leydig cells possess stereospecific receptors for LHRH-like peptides; putative candidates for these peptides have been isolated from the testis, and LHRH and its agonists have been shown to have direct stimulatory and inhibitory effects on testicular microcirculation, LH receptors and steroidogenesis in rats (Hsueh \& Jones, 1981; Bourne, Dockrill, Regiani, Marshall \& Payne, 1982; Sharpe, Fraser, Cooper \& Rommerts, 1982; Sharpe et al., 1983; Sharpe \& Cooper, 1983; Browning, D'agata, Steinberger, Grotjan \& Steinberger, 1983; Damber, Widmark \& Bergh, 1985). However, the chemical identity and the physiological role of these putative peptides presumably secreted by the Sertoli cells is far from resolved (Hedger, Robertson, Browne \& de Kretser, 1984; Huhtaniemi \& Catt, 1985; Melson, Brown, Schoenemann, Tarnavsky \& Reeves, 1986). Considerable variation in the reported molecular weights of these substances seems to exist (Arimura \& Turkelson, 1984).

Interstitial macrophages are closely associated with Leydig cells and their functional state is related to that of interstitial cells. Macrophages are also steroidogenic and possess common surface antigens with Leydig cells (Milewich et al., 1982; Molenaar, Rommerts \& van der Molen, 1984; Bergh, 1985). It has even been suggested that these cells are precursors for Leydig cells (Clegg \& Macmillan, 1965; Wartenberg, 1981). Some studies suggest that macrophages possess FSH receptors (Hovatta, Nikula, Wahlström \& Huhtaniemi, 1985; Yee \& Hutson, 1985). It has been known for some time that FSH also modulates Leydig cell function, i.e. induces LH receptors and increases the steroidogenic capacity of the testis, and that FSH and LH seem to have synergistic

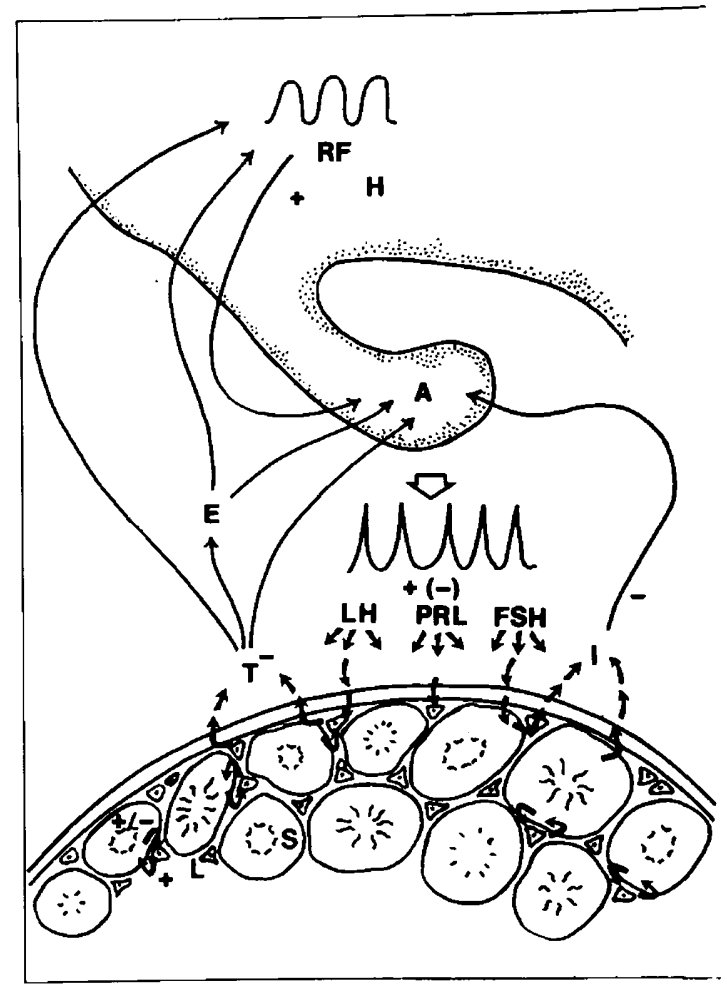

Fig. 1. Main features in the hormonal and paracrine control of testicular function. $\mathbf{H}=$ hypothalamus; $\mathbf{A}=$ hypophysis; $\mathbf{S}=$ seminiferous tubule; $\mathbf{L}=$ Leydig cell; $\mathbf{R F}=$ releasing factors $\mathbf{P R L}=$ prolactin; $\mathbf{T}=$ testosterone; $\mathbf{E}=$ oestradiol; $\mathbf{I}=$ inhibin; $+\mathbf{+}=$ stimulation; $-=$ inhibition. 


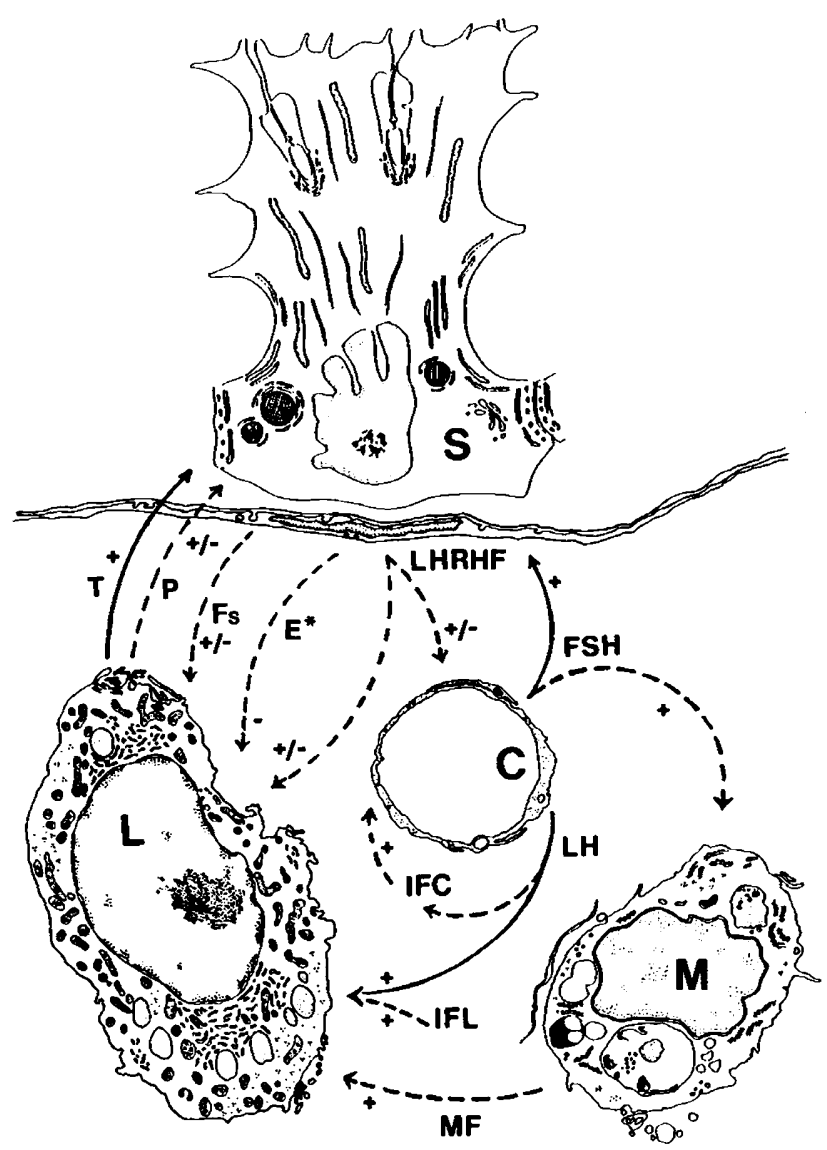

Fig. 2. Paracrine regulation in the testis. Solid arrows represent established regulatory interactions whereas the broken ones indicate emerging concepts of paracrine control. $\mathbf{S}=$ Sertoli cell; $\mathbf{L}=$ Leydig cell; $\mathbf{M}=$ macrophage $\mathbf{C}=$ capillary; $\mathbf{P}=$ pro-opiomelanocortin derived peptides; Fs = unknown factors of Sertoli cell origin; LHRHF = LHRH-like factor(s); IFL = factor(s) in the interstitial fluid which modulate Leydig cell function; IFC $=$ factor(s) in the interstitial fluid which regulate capillary permeability when activated by $\mathbf{L H} ; \mathbf{M F}=$ factor(s) secreted by macrophages which modulate Leydig cell function. * = synthesis possibly restricted to the prepubertal period; $+=$ stimulation, or increased capillary permeability or vascular resistance; - = inhibition, or decreased capillary permeability or vascular resistance.

effects on testicular function (Johnson \& Ewing, 1971; Chen, Shaw \& Payne, 1977; Shaw, Georgopoulos \& Payne, 1979; Moger \& Murphy, 1982; Benahmed, Reventos, Tabone \& Saez, 1984; Kerr \& Sharpe, 1985). It is therefore possible that the effects of FSH are not merely conveyed through functional changes in Sertoli cells (Benahmed, Morera, Sanchez, Berthelon \& Grenot, 1985 ) but that also 'FSH-induced' changes in macrophage function are involved (Yee \& Hutson, 1985).

Since all paracrine interactions involving the Leydig cell take place in the interstitial fluid, local changes in its volume and chemical composition is of primary regulatory importance. Indeed LHRH and hCG have been shown to induce changes in testicular vascular resistance and capillary permeability (Damber et al., 1985; Veijola \& Rajaniemi, 1985). Moreover, recent studies suggest that the interstitial fluid contains factors which mediate and potentiate the effects of LH on 
capillary permeability and steroidogenesis (Veijola \& Rajaniemi, 1985; Rommerts, Hoogerbrugge \& van der Molen, 1985; Sharpe \& Bartlett, 1985).

The functional state of the Leydig cell is predominantly determined by the pituitary secretion of gonadotrophins, prolactin (Fig. 1) and possibly also ACTH (Bartke, 1971; Liptrap \& Raeside, 1975; Juniewicz \& Johnson, 1981, 1983; Bartke, Klemcke \& Matt, 1985b). However, the integration and coordination of Leydig cell and seminiferous tubule function is achieved through relatively sophisticated paracrine and autocrine regulatory interactions (Fig. 2) involving numerous bioactive compounds of which many share similarities with hormonally active peptides previously described in the central nervous system.

\section{The membrane: transmission and modulation of the hormonal signal}

\section{Signal transmission}

The hormonal message conveyed by gonadotrophins is transmitted to the target cells through a receptor-mediated process on the cell membrane. The LH receptors, as well as the cascade of events within the membrane triggered by the hormone-receptor interaction, are of primary importance in mediating the LH signal to the intracellular compartment of the Leydig cell. The binding of LH to its respective receptors, which are dimeric transmembrane glycoproteins $\left(M_{\mathrm{r}} 190000\right)$, triggers a series of reactions within the membrane leading eventually to the activation of adenylate cyclase. Although causal relationships are hard to establish it would seem that the hormone-receptor interaction activates a large number of nucleotide regulatory units resulting in an increased binding of GTP to the membrane and a subsequent phosphorylation of specific membrane protein(s) and the activation of adenylate cyclase (Dufau, Baukal Catt, 1980; Dufau et al., 1984). In addition to guanyl nucleotides and the phosphorylation of membrane proteins, methylation processes and cytoskeletal elements seem to be involved in the activation of adenylate cyclase as well as in subsequent cytosolic events (Carreau, Papadopoulos \& Drosdowsky, 1985). $\mathrm{Ca}^{2+}$ also seems to have a regulatory role in the control of Leydig cell steroidogenesis (Hall, Osawa \& Mrotek, 1981; Cooke \& Sullivan, 1985). Some studies suggest that calmodulin is involved in the transport of cholesterol to the mitochondria and that, in addition to the classical cAMP-dependent protein kinase pathway, $\mathrm{Ca}^{2+} /$ phospholipid-dependent protein kinase may also be involved in the control of Leydig cell steroidogenesis (Fig. 3) (Hall et al., 1981; Welsh, Jones \& Hsueh, 1984; Lin, 1985; Themmen, Hoogerbrugge, Rommerts \& van der Molen, 1985b; Cooke \& Sullivan, 1985). In fact the studies of Themmen, Hoogerbrugge, Rommerts \& van der Molen (1985a) and Themmen et al. (1985b) suggest that cAMP is not obligatory for the stimulation of Leydig cell steroidogenesis.

Although $\mathrm{LH}$ is the primary hormonal factor regulating Leydig cell function, these cells receive other hormonal and paracrine input. Stereospecific receptors for prolactin, AVT- and LHRHlike substances, insulin-like growth factor, epidermal growth factor, catecholamines and benzodiazepine have been localized on the rat Leydig cell membrane (Fig. 3) (Ascoli, 1981; Huhtaniemi \& Catt, 1981; Welsh \& Hsueh, 1982; Bourne et al., 1982; Meidan \& Hsueh, 1985; De Souza, Anholt, Murphy, Snyder \& Kuhar, 1985; Handelsman, Spaliviero, Scott \& Baxter, 1985; Anakwe, Moger \& Nance, 1985).

Some of these endocrine and paracrine factors seem to use second messengers other than cAMP. The testicular LHRH-like factor induces changes in phosphatidyl inositol turnover, $\mathrm{Ca}^{2+}$ permeability and prostaglandin E production, whereas the effects of prolactin are possibly conveyed by a peptide cleaved from the receptor itself (Kelly et al., 1984; Cooke, Dix, Habberfield \& Sullivan, 1984; Molcho, Zakut \& Naor, 1984). However, AVT seems to exert its influence via the inhibitory membrane protein $\mathrm{Ni}$, the universal coupler of inhibitory receptors to adenylate cyclase (Adashi, Resnik, Cronin \& Hewlett, 1984). How are these multiple incoming signals integrated at the level of the Leydig cell membrane? Although many aspects of these mechanisms remain obscure, it would seem that the integration of adenylate cyclase-dependent inhibitory and 


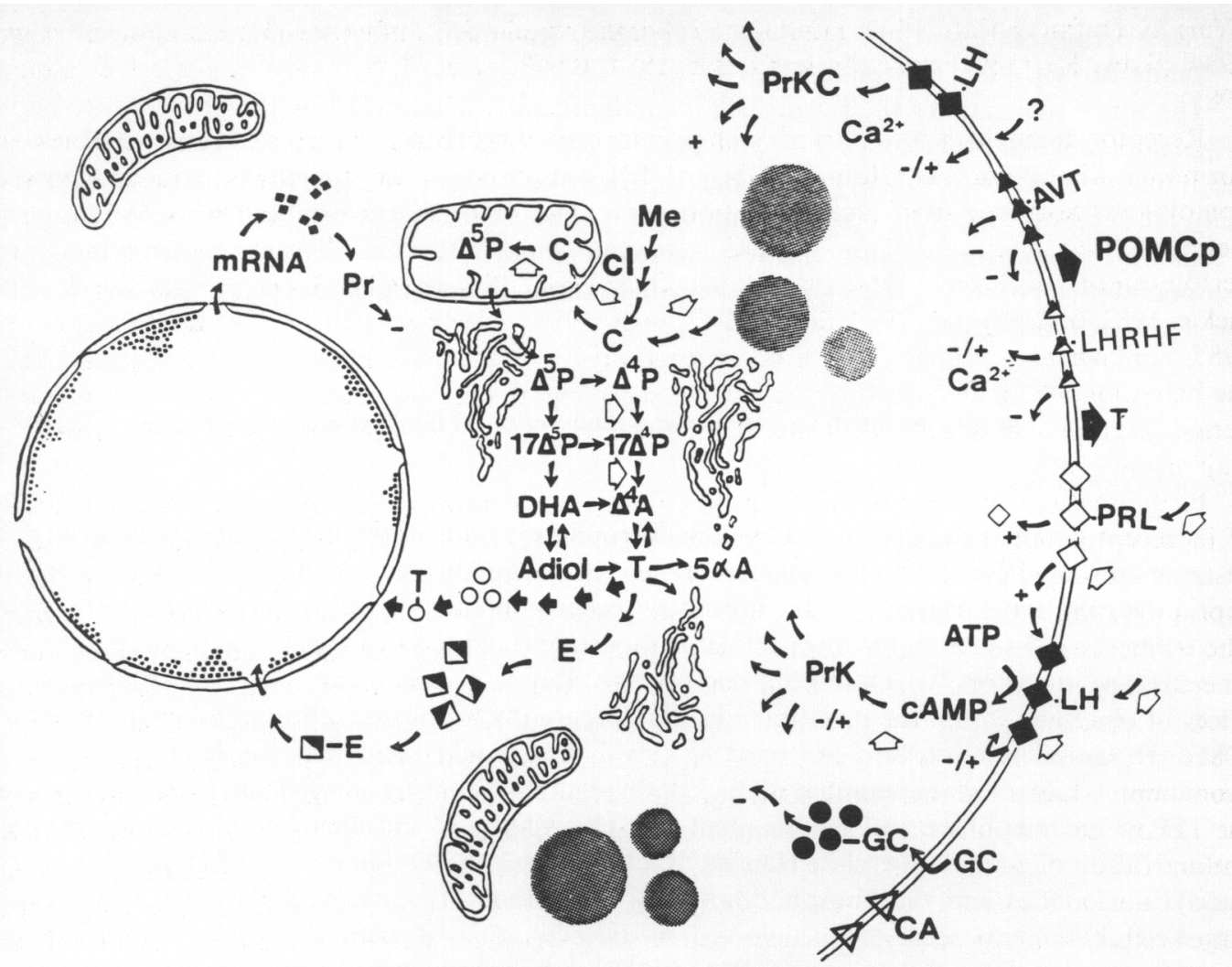

Fig. 3. Some aspects of Leydig cell function and its regulation. White arrows indicate established key enzymic reactions and hormones involved in the control of Leydig cell LH receptors and steroidogenesis. The physiological significance and the general relevance of many of the other regulatory mechanisms presented remain obscure. POMCP $=$ pro-opiomelanocortin-derived peptides; LHRHF = LHRH-like factor(s); AVT = arginine vasotocin-like factor(s); $\mathbf{G C}=$ glucocorticoids; $\mathbf{C A}=$ catecholamines; $\mathbf{P r K}=$ cAMP-dependent protein kinase; PrKC = $\mathrm{Ca}^{2+} /$ phospholipid-dependent protein kinase; $\mathbf{M e}=$ mevalonate; $\mathbf{C}=$ cholesterol; $\mathbf{C I}=$ calmodulin; $\Delta^{5} \mathbf{P}=$ pregnenolone; $\Delta^{4} \mathbf{P}=$ progesterone; $17 \Delta^{5} \mathbf{P}=17 \alpha$-hydroxypregnenolone; $17 \Delta^{4} \mathbf{P}=17 \alpha$-hydroxyprogesterone; $\mathbf{D H A}=$ dehydroepiandrosterone; $\Delta^{4} \mathbf{A}=$ androstenedione; $5 \alpha \mathbf{A}=5 \alpha$-androstanediol; $\quad \mathbf{P r}=$ protein; $\quad$ Adiol $=$ androstenediol; $\quad ?=$ chemically undefined factors; $+=$ stimulation of androgen synthesis (in association with arrows pointing towards the smooth endoplasmic reticulum) or up - regulation of $\mathrm{LH}$ receptors (in association with arrows pointing towards the cell membrane); $-=$ inhibition of androgen synthesis or down-regulation of $\mathrm{LH}$ receptors.

excitatory input is achieved by coupler proteins within the membrane. Functional interactions between $\mathrm{Ca}^{2+}$ and cAMP-mediated control mechanisms also seem to exist (Rasmussen, 1980; Tsang \& Carnegie, 1983; Cooke et al., 1984; Peake \& Smoake, 1985).

\section{Signal modulation}

Since the chemical signals have to traverse the plasma membrane to control the cytoplasmic and genomic events within the target cells, the membrane comprises an important regulatory site for modulating incoming hormonal input. Indeed the transmission of the hormonal signal is not a rigidly constant process for a given chemical effector but a flexible and adaptive one, which is dependent on the dose of the hormone as well as the developmental stage of the target cells 
(Warren, Dufau \& Catt, 1982; Huhtaniemi, Bergh, Nikula \& Damber, 1984a; Huhtaniemi et al., 1984b; Irby, Kerr, Risbridger \& de Kretser, 1984; Bartke et al., 1985a; Moyle, Kuczek \& Bailey, 1985).

Receptor regulation is of primary importance in modulating target cell responsiveness to hormonal stimulation. The total number of $\mathrm{LH}$ receptors per Leydig cell is regulated by the homologous hormone itself (autoregulation) as well as by other chemical effectors such as prolactin, FSH, oestrogen, AVT- and LHRH-like factors and by chemically undefined substances of Sertoli cell origin (heterologous regulation) (Chen et al., 1977; Bartke, Klemcke, Amador \& Van Sickle, 1982; Sharpe et al., 1982; Sharpe \& Cooper, 1983; Adashi \& Resnik, 1984; Benahmed et al., 1985; Stallings et al., 1985). In rodents, at least, prolactin and FSH seem to have a central role in the heterologous regulation of $\mathrm{LH}$ receptors, especially in receptor induction during the pubertal period (Huhtaniemi \& Catt, 1981; Klemcke, Bartke \& Borer, 1984; Stallings et al., 1985; Tähkä \& Rajaniemi, 1985).

In the mature rat LH modulates the sensitivity of the Leydig cells by regulating the number of its receptors on the membrane. A single physiological dose of LH induces a rather slow and sustained up-regulation of homologous receptors (evident after 1-2 days), whereas a single supraphysiological dose results in a more rapid (3-6h after administration) receptor increase. The former seems to be due to the trophic actions of $\mathrm{LH}$ on receptor induction and maintenance whereas the latter is evidently the result of the 'unmasking' of cryptic receptors and/or the incorporation of presynthesized receptors into the membrane (Huhtaniemi, Katikineni, Chan \& Catt, 1981a; Dufau et al., 1984). After the initial transient up-regulation, high doses of LH induce a prominent reduction (down-regulation) in $\mathrm{LH}$ receptor numbers and an impaired responsiveness of the Leydig cell to subsequent hormone stimulation (desensitization) (Nozu, Matsuura, Catt \& Dufau, 1981a; Nozu, Dehejia, Zawistowich, Catt \& Dufan, 1981b, 1982). Desensitization is due to the combined effects of $\mathrm{LH}$-induced receptor loss as well as to specific steroidogenic lesions in the target cells (Dufau et al., 1979). At the membrane level there seems to be an uncoupling of the hormone-receptor complex from adenylate cyclase, its subsequent proteolysis and internalization (homologous desensitization) (Rajaniemi, Manninen \& Huhtaniemi, 1979; Kirchick, Iyengar \& Birnbaumer, 1983; Kellokumpu \& Rajaniemi, 1985) as well as a decrease in the activity of the nucleotide-binding regulatory component (heterologous desensitization) (Kirchick et al., 1983; Dufau et al., 1984). In heterologous desensitization, therefore, responsiveness of the adenylate cyclase is lost not only to the homologous hormone but also to other cAMP dependent stimulatory agents. It has been sliggested that these membrane events are due to the specific phosphorylation of receptors as well as the $\mathrm{N}$ terminal component (Kirchick et al., 1983). High doses of LH have also been observed to induce up- and subsequent down-regulation of Leydig cell prolactin receptors (heterologous regulation) (Davies et al., 1979; Huhtaniemi, Warren \& Catt, 1983).

Desensitization seems to be specific for the mature Leydig cells. The interstitial cells of fetal, neonatal, prepubertal and seasonally quiescent animals respond to desensitizing doses of hCG with an increase in testosterone synthesis and LH receptor numbers (Warren et al., 1982; Huhtaniemi, Katikineni \& Catt, 1981b; Huhtaniemi, Nozu, Warren, Dufau \& Catt, 1982; Huhtaniemi et al., 1984b; Amador, Bartke, Klemcke, Siler-Khodr \& Stallings, 1985; Amsterdam, Venter \& Huhtaniemi, 1985). It has been proposed that the lack of heterologous and homologous downregulation in the Leydig cells of neonatal and fetal animals is an adaptation to high levels of placental hCG and reflects the need for high androgen concentrations during differentiation of the genitalia and the masculinization of hypothalamic structures in the male fetus (Huhtaniemi et al., 1984b).

\section{Intracellular events: regulation of steroidogenic elements}

The Leydig cell is a highly differentiated cell specialized in the synthesis and secretion of androgens. The array of enzymes participating in steroidogenesis are strictly compartmentalized between the 
mitochondria, SER and the cytoplasm (Ewing \& Zirkin, 1983). The differentiated state of these Leydig cell organelles as well as the induction and maintenance of the steroidogenic enzymes is under the trophic control of pituitary LH and prolactin (Fig. 3) (Dufau, Hsueh, Cigorraga, Baukal \& Catt, 1978; Bartke et al., 1985b). In addition to trophic actions, LH has also acute effects on Leydig cell steroidogenesis (Purvis, Cusan \& Hansson, 1981). However, the steroidogenic response of the Leydig cell to an LH signal is not stereotypic but dependent on the LH dose as well as the developmental stage of the gonads (Ficher \& Steinberger, 1971; Huhtaniemi et al., 1982, 1984a,b; Tähkä, Teräväinen \& Wallgren, 1982, 1983b; Tähkä, Ruokonen, Wallgren \& Teräväinen, 1983a; Teräväinen \& Tähkä, 1985; Bartke et al., 1985a; Moyle et al., 1985). It seems that the dose- as well as the age-dependent differences in the steroidogenic response of Leydig cells are not merely quantitative in nature (Ficher \& Steinberger, 1971; Lacroix, Eechaute \& Leusen, 1977; Eechaute, Lacroix \& Leusen, 1980). In many rodents, during the prepubertal period there is a qualitative shift from the production of hormonally active $\mathrm{C}_{19}$ steroids to that of $5 \alpha$ - and $5 \beta$-reduced androgens (Ficher \& Steinberger, 1971; Terada, Sato \& Matsumoto, 1980; Tsuji et al., 1984).

Physiological doses of LH induce an acute stimulation of steroid production, mainly by modulating the hydrolysis of cholesterol esters, the permeability of the mitochondrial membrane to cholesterol and the activity of the enzymes catalysing cholesterol side-chain cleavage (Hall, Charponnier, Nakamura \& Gabbiania, 1979; Mori \& Marsh, 1982).

It has been established that the stimulatory effects of LH on androgen synthesis are mainly brought about by changes in the production of intracellular cAMP, the subsequent activation of protein kinase and the phosphorylation of specific proteins and the eventual increase in the activity of steroidogenic enzymes (Purvis et al., 1981; Dufau et al., 1984). Some recent data suggest, however, that calmodulin- and $\mathrm{Ca}^{2+}$-activated phospholipid-dependent protein kinase are involved in the regulation of Leydig cell steroidogenesis (Fig. 3) Hall et al., 1981; Welsh et al., 1984; Kimura, Katoh, Sakurada \& Kubo, 1984; Lin, 1985; Nikula, Parvinen \& Huhtaniemi, 1985; Themmen et al., 1985b).

In the mature rat, Leydig cell desensitization is not merely associated with a modification of membrane events but also by functional changes in the intracellular androgen synthesizing elements. Desensitization at the intracellular level is associated with several specific steroidogenic lesions in testosterone biosynthesis, which seem to be related but not causally linked to the degree of down-regulation (receptor loss) induced by hCG. Lower doses of hCG (resulting in $50 \%$ receptor loss) induce a 'late' steroidogenic lesion that results from a decrease in the activity of the microsomal enzymes $17 \alpha$-hydroxylase and $C_{17-20}$ lyase which catalyse the conversion of $C_{21}$ steroids to androgens (Dufau et al., 1979; Nozu et al., 1981a). This 'late' lesion is thought to be the result of an ultrashort negative feedback action of oestrogen on Leydig cell steroidogenesis (Fig. 3) (autocrine regulation). Other intracellularly produced steroids also seem to exert regulatory effects on testosterone synthesis. These regulatory interactions are either receptor mediated, involving transcriptional events, or based on the direct inhibition of steroidogenic enzymes (Fan, Oshima, Troen \& Troen, 1974; Rosness, Sunde \& Eik-Nes, 1977; Hosaka, Oshima \& Troen, 1980; Galarreta, Fanjul, Adashi \& Hsueh, 1984; Kuhn-Velten \& Staib, 1984b). It has been suggested that the 'late' steroidogenic lesion is brought about by an hCG/LH-induced increase in Leydig cell oestrogen synthesis which in turn, through a receptor-mediated process, inhibits the activity of the cytochrome P450-dependent microsomal enzymes (Nozu et al., 1981b, 1982; Tsai-Morris, Aquilano \& Dufau, 1985). Several other effectors, such as glucocorticoids, epidermal growth factor and LHRH- and AVT-like factors as well as proteins of Sertoli cell origin, which have been proposed as participants in the endocrine and paracrine control of testicular function, modulate the activity of $17 \alpha$-hydroxylase and $C_{17-20}$ lyase (Sharpe, 1982; Hsueh, 1982; Welsh, Bambino \& Hsueh, 1982; Welsh \& Hsueh, 1982; Adashi \& Hsueh, 1982; Hsueh, Bambino, Zhuang, Welsh \& Ling, 1983; Verhoeven \& Cailleau, 1985; Kasson \& Hsueh, 1986).

The absence of steroidogenic lesions in the fetal and neonatal rat Leydig cells exposed to desensitizing doses of hCG is partly attributed to the lack of oestrogen receptors in these cells 
(Huhtaniemi et al., 1984b). However, the role of oestrogen in the induction of the 'late' steroidogenic lesion is still controversial (Kuhn-Velten \& Staib, 1984a; Quinn \& Payne, 1985).

An 'early' steroidogenic lesion before pregnenolone formation can be detected in Leydig cells exposed to high desensitizing doses of hCG (resulting in $70 \%$ receptor loss). This early lesion is thought to be caused by a decrease in the activity of 3-hydroxy-3-methylglutaryl Coenzyme A reductase as well as by a hCG-induced activation or increase in a intramitochondrial protein which inhibits cholesterol side-chain cleavage activity (Charreau et al., 1981; Hattori, Aquilano \& Dufau, 1984; Aquilano, Tsai-Morris, Hattori \& Dufau, 1985).

In addition to these steroidogenic lesions, chronic hCG and LHRH treatment seems to cause, in the mature rat, a qualitative shift from the normal dominating $7 \alpha$-hydroxylation pathways to $5 \alpha$-reduction pathways (Eechaute et al., 1980; Carmichael et al., 1980; Lacroix et al., 1977, 1984). There is therefore a shift from a adult type of steroidogenic pattern to one similar to that observed in immature testes (Ficher \& Steinberger, 1971; Rosness et al., 1977; Terada et al., 1980; Tsuji et al., 1984). The functional significance of such multistep control is unknown but there may be some physiological significance in the accumulation of specific steroid metabolites in testes exposed to different doses of $\mathrm{hCG} / \mathrm{LH}$.

\section{References}

Adashi, E.Y. \& Hsueh, A.J.W. (1982) Direct inhibition of rat testicular androgen biosynthesis by arginine vasotocin. Studies on mechanism of action. J. biol. Chem. 257, 1301-1308.

Adashi, E.Y. \& Resnik, C.E. (1984) 'Antigonadal' activity of the neurohypophyseal hormones: Direct in vivo regulation of Leydig cell function. Annls N.Y. Acad. Sci. 438, 622-624.

Adashi, E.Y., Resnik, C.E., Cronin, M.J. \& Hewlett, E.L. (1984) 'Antigonadal' activity of the neurohypophyseal hormones in cultured rat testicular cells: abolition by pertusis toxin. Biol. Reprod. 30, Suppl. 1, 133, Abstr.

Amador, A., Bartke, A., Klemcke, H.G., Siler-Khodr, T.M. \& Stallings, M.H. (1985) Effects of photoperiod and hCG on the regulation of testicular LH/hCG receptors in Syrian hamsters (Mesocricetus auratus). J. Reprod. Fert. 74, 693-700.

Amsterdam, A., Venter, A. \& Huhtaniemi, I. (1985) Distribution of $\mathrm{LH}$ receptors in testis of neonatal rats revealed by high resolution autoradiography. Biol. Reprod. 32, Suppl. 1, 188, Abstr.

Anakwe, O.O., Moger, W.H. \& Nance, D.M. (1985) Catecholamine stimulation of testicular steroidogenesis. Biol. Reprod. 32, Suppl. 1, 85, Abstr.

Aoki, A. \& Fawcett, D.W. (1978) Is there a local feedback from the seminiferous tubules affecting activity of the Leydig cell. Biol. Reprod. 19, 144-158.

Aquilano, D.R., Tsai-Morris, C., Hattori, M. \& Dufau, M.L. (1985) Mitochondrial cholesterol availability during gonadotropin-induced Leydig cell desensitization. Endocrinology 116, 1745-1754.

Arimura, A. \& Turkelson, C.M. (1984) LHRH-like substance in the rat testis. Annls N.Y. Acad. Sci. 438, 390-393.

Ascoli, M. (1981) Regulation of gonadotropin receptors and gonadotropin responses in a clonal strain of Leydig tumor cells by epidermal growth factor. $J$. biol. Chem. 256, 179-183.
Bardin, C.W., Shaha, C., Mather, J., Salomon, Y., Margioris, A.N., Liotta, A.S., Gerendai, I., Chen, C.-L. \& Krieger, D.T. (1984) Identification and possible function of pro-opiomelanocortin-derived peptides in the testis. Annls N.Y. Acad. Sci. 438, 346-364.

Barr, D.B. \& Pomerantz, D.K. (1984) Leydig cell function in hypophysectomized adult rats is dependent upon dose and temporal pattern of gonadotropin treatment. Biol. Reprod. 30, Suppl. 1, 50, Abstr.

Bartke, A. (1971) Effects of prolactin and luteinizing hormone on the cholesterol stores in the mouse testis. J. Endocr. 49, 317-324.

Bartke, A., Klemcke, H.G., Amador, H. \& Van Sickle, M. (1982) Photoperiod and regulation of gonadotropin receptors. Annls N.Y. Acad. Sci. 383, 122-131.

Bartke, A., Matt, K.S., Amador, A.G., Klemcke, H.G., Brown, D., Gonzales, D. \& Morgan, M.P. (1985a) Effects of inhibitory and stimulatory photoperiods and sexual maturation on the ability of hamster testes to respond to hCG in vitro. Int. J. Androl. 8, 232-242.

Bartke, A., Klemcke, H. \& Matt, K. (1985b) Effects of physiological and abnormally elevated prolactin levels on the pituitary-testicular axis. Med. Biol. 63, 264-272.

Benahmed, M., Reventos, J., Tabone, E. \& Saez, J.M. (1984) Synergistic effects of Sertoli cell and FSH on Leydig cell function: in vitro study. Annls N.Y. Acad. Sci. 438, 684-687.

Benahmed, M., Morera, A.M., Sanchez, P., Berthelon, M.C. \& Grenot, C. (1985) Identification from Sertoli cell conditioned medium of proteins which regulate Leydig cell activity. Acta endocr., Copenh., Suppl. 270, 211, Abstr.

Bergh, A. (1982) Local differences in Leydig cell morphology in the adult rat testis: evidence for a local control of Leydig cells by adjacent seminiferous tubules. Int. J. Androl. 5, 325-330. 
Bergh, A. (1983) Paracrine regulation of Leydig cells by the seminiferous tubules. Int. J. Androl. 6, 57-65.

Bergh, A. (1985) Effect of cryptorchidism and hCG on the morphology of testicular macrophages - evidence for a macrophage Leydig cell interaction in the rat testis? Acta endocr., Copenh., Suppl. 270, 212, Abstr.

Bouin, P. \& Ancel, P. (1903) Recherches sur les cellules interstitielles du testicule des mammiferes. Arch. Zool. exp. Gén. 1, 437-523.

Bourne, G.A., Dockrill, M.R., Regiani, S., Marshall, J.C. \& Payne, A.H. (1982) Induction of testicular gonadotropin-releasing hormone $(\mathrm{GnRH})$ receptors by GnRH: effects of pituitary hormones and relationship to inhibition of testosterone production. Endocrinology 110, 727-733.

Browning, J.Y., D'agata, R., Steinberger, A., Grotjan, H.E. \& Steinberger, E. (1983) Biphasic effect of gonadotropin-releasing hormone and its agonist analog (HOE766) on in vitro testosterone production by purified rat Leydig cells. Endocrinology 113, 985-991.

Callard, G.V., Pudney, J.A., Mak, P. \& Canik, J.A. (1985) Stage-dependent changes in steroidogenic enzymes and estrogen receptors during spermatogenesis in the testis of the dogfish, Squalus acanthias. Endocrinology 117, 1328-1335.

Carmichael, R., Belanger, A., Cusan, L., Seguin, C., Caron, S. \& Labrie, F. (1980) Increased testicular $5 \alpha$-androstane- $3 \alpha, 17 \beta$-diol formation induced by treatment with (D-Ser(TBU) ${ }^{6}$, Des-Gly- $\mathrm{NH}_{2} 10$ ) LHRH ethylamide in the rat. Steroids 36, 383-390.

Carreau, S., Papadopoulos, V. \& Drosdowsky, M.A. (1985) Implication of membrane and cytosolic methylation processes in the regulation of rat Leydig cell steroidogenesis. Acta endocr., Copenh., Suppl. 270, 201, Abstr.

Charreau, E.H., Calvo, J.C., Nozu, K., Pignataro, O., Catt, K.J. \& Dufau, M.L. (1981) Hormonal modulation of 3-hydroxy-3-methylglutaryl coenzyme A reductase activity in gonadotropin-stimulated and -desensitized testicular Leydig cells. J. biol. Chem. 256, 12719-12724.

Chen, Y.D.I., Shaw, M.J. \& Payne, A.H. (1977) Steroid and FSH action on $\mathrm{LH}$ receptors and LH-sensitive testicular responsiveness during sexual maturation of the rat. Molec. cell. Endocrinol. 8, 291-299.

Clegg, E.J. \& Macmillan, E.W. (1965) The phagocytic nature of Schiff-positive interstitial cells in the rat testis. J. Endocr. 31, 299-300.

Conn, P.M., Cooper, R., McNamara, C., Rogers, D.C. \& Shoenhardt, L. (1980) Qualitative change in gonadotropin during normal aging in the male rat. Endocrinology 106, 1549-1553.

Cooke, B.A. \& Sullivan, M.H.F. (1985) Modulation and role of $\mathrm{Ca}^{2+}$ in $\mathrm{LH}$ and LHRH agonist action in rat Leydig cells. Med. Biol. 63, 259-263.

Cooke, B.A., Dix, C.J., Habberfield, A.D. \& Sullivan, M.H.F. (1984) Control of steroidogenesis in Leydig cells: roles of $\mathrm{Ca}^{2+}$ and lipoxygenase products in $\mathrm{LH}$ and LHRH agonist action. Annls N.Y. Acad. Sci. 438, 269-282.

Damber, J.-E., Widmark, A. \& Bergh, A. (1985) Changes of testicular vascular resistance after treatment of rats with an LHRH-agonist. Acta endocr., Copenh., Suppl. 270, 205, Abstr.
Dave, J.R., Rubinstein, N. \& Eskay, R.L. (1985) Evidence that $\beta$-endorphin binds to specific receptors in rat peripheral tissues and stimulates the adenylate cyclase-adenosine $3^{\prime}, 5^{\prime}$-monophosphate system. Endocrinology 117, 1389-1396.

Davies, T.F., Katikineni, M., Chan, V., Harwood, J.P., Dufau, M.L. \& Catt, K.J. (1979) Lactogenic receptor regulation in hormone-stimulated steroidogenic cells. Nature, Lond. 283., 863-865.

De Souza, E.B., Anholt, R.R.H., Murphy, K.M.M., Snyder, S.H. \& Kuhar, M.J. (1985) Peripheral-type benzodiazepine receptors in endocrine organs: autoradiographic localization in rat pituitary, adrenal, and testis. Endocrinology 116, 567-573.

di Zerega, G.S. \& Sherins, R.J. (1981) Endocrine control of adult testicular function. In The Testis, pp. 127-140. Eds H. Burger \& D. M. de Kretser. Raven Press, New York.

Dufau, M.L., Hsueh, A.J., Cigorraga, S., Baukal, A.J. \& Catt, K.J. (1978) Inhibition of Leydig cell function through hormonal regulatory mechanisms. Int. $J$. Androl., Suppl. 2, 193-239.

Dufau, M.L., Cigorraga, S., Baukal, A.J., Sorrell, S., Bator, J.M., Neubauer, J.F. \& Catt, K.J. (1979) Androgen biosynthesis in Leydig cells after testicular desensitization by luteinizing hormone- releasing hormone and human chorionic gonadotropin. Endocrinology 105, 1314-1321.

Dufau, M.L., Baukal, A.J. \& Catt, K.J. (1980) Hormoneinduced guanyl nucleotide binding and activation of adenylate cyclase in the Leydig cell. Proc. natn. Acad. Sci. U.S.A. 77, 5837-5841.

Dufau, M.L., Winters, C.A., Hattori, M., Aquilano, D., Baranao, J.L.S., Nozu, K., Baukal, A. \& Catt, K.J. (1984) Hormonal regulation of androgen production by the Leydig cell. J. Steroid Biochem. 20, 161-173.

Eechaute, W., Lacroix, E. \& Leusen, I. (1980) Kinetic study of HCG induced decrease of microsomal $7 \alpha$-hydroxylase activity in rat testes. Steroids 36, $647-660$.

Eik-Nes, K.B. (1975) Biosynthesis and secretion of testicular steroids. In Handbook of Physiology, pp. 95-115. Eds R. O. Greep, E. B. Astwood, D. W. Hamilton \& S. Geiger. American Physiol. Soc., Washington D.C.

Ellis, G.B. \& Desjardins, C. (1982) Male rats secrete luteinizing hormone and testosterone episodically. Endocrinology 110, 1618-1627.

Ellis, G.B. \& Desjardins, C. (1984a) Orchidectomy unleashes pulsatile luteinizing hormone secretion in the rat. Biol. Reprod. 30, 619-627.

Ellis, G.B. \& Desjardins, C. (1984b) Mapping episodic fluctuations in plasma $\mathbf{L H}$ in orchidectomized rats. Am. J. Physiol. 247 (Endocrinol. Metab. 10), E130-E135.

Ellis, G.B., Desjardins, C. \& Fraser, H.M. (1983) Control of pulsatile LH release in male rats. Neuroendocrinology 37, 177-183.

Ewing, L.L. \& Zirkin, B. (1983) Leydig cell structure and steroidogenic function. Recent Prog. Horm. Res. 39, 599-632.

Fabbri, A., Tsai-Morris, C.H., Luna, S., Fraioli, F. \& Dufau, M.L. (1985) Opiate receptors are present in the rat testis. Identification and localization in Sertoli cells. Endocrinology 117, 2544-2546. 
Fan, D., Oshima, H., Troen, B.R. \& Troen, P. (1974) Studies of the human testis. IV. Testicular 20ahydroxysteroid dehydrogenase and steroid $17 \alpha-$ hydroxylase. Biochim. Biophys. Acta 360, 88-99.

Ficher, M. \& Steinberger, E. (1971) In vitro progesterone metabolism by rat testicular tissue at different stages of development. Acta endocr., Copenh. 68, 285-292.

Galarreta, C.M.R., Fanjul, L.F., Adashi, E.Y. \& Hsueh, A.J.W. (1984) Regulation of 3 $\beta$-hydroxysteroid dehydrogenase activity by human chorionic gonadotropin, androgens, and antiandrogens cultured testicular cells. Annls N.Y. Acad. Sci. 438, 663-665.

Hall, P.F., Charponnier, C., Nakamura, M. \& Gabbiani, G. (1979) The role of microfilaments in the response of Leydig cells to LH. J. Steroid Biochem. 11, 1361-1366.

Hall, P.F., Osawa, S. \& Mrotek, J. (1981) The influence of calmodulin on steroid synthesis in Leydig cells from rat testis. Endocrinology 109, 1677-1682.

Handelsman, D.J., Spaliviero, J.A., Scott, C.D. \& Baxter, R.C. (1985) Identification of insulin-like growth factor-I and its receptors in the rat testis. Acta endocr., Copenh. 109, 543-549.

Hattori, M., Aquilano, D.R. \& Dufau, M.L. (1984) An early steroidogenic defect in hormone-induced Leydig cell desensitization. J. Steroid Biochem. 21, 265-277.

Hedger, M.P., Robertson, D.M., Browne, C.A. \& de Kretser, D.M. (1984) Studies on the identification of a LHRH-like peptide in the rat testis. Annls N.Y. Acad. Sci. 438, 37I-381.

Hosaka, M., Oshima, H. \& Troen, P. (1980) Studies of the human testis. XIV. Properties of $\mathrm{C}_{17-20}$ lyase. Acta endocr., Copenh. 94, 389-396.

Hovatta, O., Nikula, H., Wahlström, T. \& Huhtaniemi, I.T. (1985) Immunohistochemical demonstration of gonadotrophins in rat testicular macrophages and Leydig cells. Acta endocr., Copenh., Suppl. 270, 217, Abstr.

Hsueh, A.J.W. (1982) Direct effects of gonadotropin releasing hormone on testicular Leydig cell functions. Annls N.Y. Acad. Sci. 383, 249-269.

Hsueh, A.J.W. \& Jones, P.B.C. (1981) Extrapituitary actions of gonadotropin-releasing hormone. Endocr. Rev. 2, 437-461.

Hsueh, A.J.W., Bambino, T.H., Zhuang, L., Welsh, T.H., Jr \& Ling, N.C. (1983) Mechanism of the direct action of gonadotropin-releasing hormone and its antagonist on androgen biosynthesis by cultured rat testicular cells. Endocrinology 112, 1653-1661.

Huhtaniemi, I.T. \& Catt, K.J. (1981) Induction and maintenance of gonadotropin and lactogen receptors in hypoprolactinemic rats. Endocrinology 109, $483-490$.

Huhtaniemi, I.T. \& Catt, K.J. (1985) Effects of gonadotropin-releasing hormone receptor blockade on rat testicular gonadotropin and lactogen receptors, steroidogenesis, and responses to human chorionic gonadotropin stimulation. Endocrinology 116, 281-287.

Huhtaniemi, I.T., Katikineni, M., Chan, V. \& Catt, K.J. (1981a) Gonadotropin-induced positive regulation of testicular luteinizing hormone receptors. Endocrinology 108, 58-65.

Huhtaniemi, I.T., Katikineni, M. \& Catt, K.J. (1981b)
Regulation of Luteinizing-hormone-receptors and steroidogenesis in the neonatal rat testis. Endocrinology 109, 588-595.

Huhtaniemi, I.T., Nozu, K., Warren, D.W., Dufau, M.L. \& Catt, K.J. (1982) Acquisition of regulatory mechanisms for gonadotropin receptors and steroidogenesis in maturing rat testis. Endocrinology 111, 1711-1720

Huhtaniemi, I.T., Warren, D.W. \& Catt, K.J. (1983) Development of heterologous down-regulation of lactogen receptors in the rat testis. Molec. cell. Endocrinol. 29, 287-294.

Huhtaniemi, I.T., Bergh, A., Nikula, H. \& Damber, J.-E. (1984a) Differences in the regulation of steroidogenesis and tropic hormone receptors between the scrotal and abdominal testes of unilaterally cryptorchid adult rats. Endocrinology 115, 550-555.

Huhtaniemi, I.T., Warren, D.W. \& Catt, K.J. (1984b) Functional maturation of rat testis Leydig cells. Annls N.Y. Acad. Sci. 438, 283-303.

Irby, D.C., Kerr, J.B., Risbridger, G.P. \& de Kretser, D.M. (1984) Seasonally and experimentally induced changes in testicular function of the Australian bush rat (Rattus fuscipes). J. Reprod. Fert. 70, 657-666.

Johnson, B.H. \& Ewing, L.L. (1971) Follicle stimulating hormone and the regulation of testosterone secretion in rabbit testis. Science, N.Y. 173, 635-637.

Juniewicz, P.E. \& Johnson, B.H. (1981) Influence of adrenal steroids upon testosterone secretion by the boar testis. Biol. Reprod. 25, 725-733.

Juniewicz, P.E. \& Johnson, B.H. (1983) Phenotypic variation in testosterone and luteinizing hormone production among boars: differential response to gonadotropin releasing hormone and adrenocorticotropic hormone. Biol. Reprod. 29, 464-471.

Karsch, F.J., Bittman, E.L., Foster, D.L., Goodman, R.L., Legan, S.J. \& Robinson, J.E. (1984) Neuroendocrine basis of seasonal reproduction. Recent Prog. Horm. Res. 40, 185-225.

Kasson, B.G. \& Hsueh, A.J.W. (1986) Arginine vasopressin as an intragonadal hormone in Brattleboro rats: presence of testicular vasopressin-like peptide and functional vasopressin receptors. Endocrinology 118, 23-31.

Kellokumpu, S. \& Rajaniemi, H. (1985) Stimulation of lutropin receptor proteolysis by hormone binding. Acta endocr., Copenh., Suppl. 270, 131, Abstr.

Kelly, P.A., Djiane, J., Katoh, M., Ferland, L.H., Houdebine, L.-M., Teyssot, B. \& Dusanter-Fourt, D. (1984) The interaction of prolactin with its receptors in target tissues and its mechanism of action. Recent Prog. Horm. Res. 40, 379-436.

Kerr, J.B. \& Sharpe, R.M. (1985) Stimulatory effect of follicle-stimulating hormone on rat Leydig cells. Cell Tiss. Res. 239, 405-415.

Kimura, F. \& Kawakami, M. (1982) Episodic LH secretion in the immature male and female rat as assessed by sequential blood sampling. Neuroendocrinology 35, 128-132.

Kimura, K., Katoh, N., Sakurada, K. \& Kubo, S. (1984) Phospholipid-sensitive $\mathrm{Ca}^{2+}$-dependent protein kinase system in testis: localization and endogenous substrates. Endocrinology 115, 2391-2399.

Kirchick, H.J., Iyengar, R. \& Birnbaumer, L. (1983) Human chorionic gonadotropin-induced hetero- 
logous desensitization of adenylyl cyclase from highly luteinized rat ovaries: attenuation of regulatory $\mathrm{N}$ component activity. Endocrinology 113, 1638-1646.

Klemcke, H.G., Bartke, A. \& Borer, K.T. (1984) Regulation of testicular prolactin and luteinizing hormone receptors in golden hamsters. Endocrinology 114, 594-603.

Kuhn-Velten, N. \& Staib, W. (1984a) Effect of human chorionic gonadotropin and estradiol in vivo on estradiol binder and cytochrome $\mathrm{P}-450$ concentrations in rat testis. J. Steroid Biochem. 20, 555-561.

Kuhn-Velten, N. \& Staib, W. (1984b) Product inhibition of steroid-17 $\alpha$-monooxygenase by endogenous $17 \alpha$ hydroxyprogesterone in microsomes and isolated Leydig cells from rat testis. J. Steroid Biochem. 21, $697-700$.

Lacroix, E., Eechaute, W. \& Leusen, I. (1977) The influence of gonadotrophin (HCG) treatment on the steroidogenesis by incubated rat testis. J. Steroid Biochem. 8, 269-275.

Lacroix, E., Eechaute, W. \& Leusen, I. (1984) Testosterone metabolism by incubated rat testes after chronic LHRH treatment. J. Steroid Biochem. 20, 633-637.

Leydig, F. (1850) Zur Anatomie der männlichen Geschlechtsorgane und Analdrusen der Säugethiere. $Z$. wiss. Zool. 2, 1-000.

Lin, T. (1985) The role of calcium/phospholipiddependent protein kinase in Leydig cell steroidogenesis. Endocrinology 117, 119-126.

Lincoln, G.A. (1981) Seasonal aspects of testicular function. In The Testis, pp. 255-302. Eds H. Burger \& D. de Kretser. Raven Press, New York.

Liptrap, R.M. \& Raeside, J.I. (1975) Increase in plasma testosterone concentration after injection of adrenocorticotrophin into the boar. $J$. Endocr. 66, 123-131.

Margioris, A.N., Liotta, A.S., Vaudry, H., Bardin, C.W. \& Krieger, T. (1983) Characterization of immunoreactive proopiomelanocortin related peptides in rat testes. Endocrinology 113, 663-671.

Meidan, R. \& Hsueh, A.J.W. (1985) Identification and characterization of arginine vasopressin receptors in the rat testis. Endocrinology 116, 416-423.

Melson, B.E., Brown, J., Schoenemann, H.M., Tarnavsky, G.K. \& Reeves, J.J. (1986) Elevation of serum testosterone during chronic LHRH agonist treatment in the bull. J. Anim. Sci. 62, 199-207.

Milewich, L., Chen, G.T., Lyons, C., Tucker, T.F., Uhr, I.W. \& MacDonald, P.C. (1982) Metabolism of androstenedione by guinea pig peritoneal macrophages: synthesis of testosterone and $5 \alpha$-reduced metabolites. J. Steroid Biochem. 17, 61-65.

Moger, W.H. \& Murphy, P.R. (1982) Reevaluation of the effect of follicle-stimulating hormone on the steroidogenic capacity of the testis: the effects of neuraminidase-treated FSH preparations. Biol. Reprod. 26, $422-428$.

Molcho, J., Zakut, H. \& Naor, Z. (1984) Gonadotropinreleasing hormone stimulates phosphatidylinositol labelling and prostaglandin E production in Leydig cells. Endocrinology 114, 1048-1050.

Molenaar, R., Rommerts, F.F.G. \& van der Molen, H.J. (1984) Characteristics of Leydig cells and macrophages from developing testicular cells. Annls N.Y. Acad. Sci. 438, 618-621.
Mori, M. \& Marsh, J.M. (1982) The site of luteinizing hormone stimulation of steroidogenesis in mitochondria of the rat corpus luteum. J. biol. Chem. 257, 6178-6183.

Moyle, W.R., Kuczek, T. \& Bailey, C.A. (1985) Potential of a quantal response as a mechanism for oscillatory behaviour: implications for our concepts of hormonal control mechanisms. Biol. Reprod. 32, 43-69.

Niḳula, H., Parvinen, M. \& Huhtaniemi, I.T. (1985) Distribution and regulation of protein kinase $\mathrm{C}$ (PK-C) activity in the rat testis tissue. Acta endocr., Copenh., Suppl. 270, 207, Abstr.

Nozu, K., Matsuura, S., Catt, K.J. \& Dufau, M.L. (1981a) Modulation of Leydig cell androgen biosynthesis and cytochrome P-450 levels during estrogen treatment and human chorionic gonadotropininduced desensitization. $J$. biol. Chem. 256, 10012-10017.

Nozu, K., Dehejia, A., Zawistowich, L., Catt, K.J. \& Dufau, M.L. (1981b) Gonadotropin-induced receptor regulation and steroidogenic lesions in cultured Leydig cells. J. biol. Chem. 256, 12875-12882.

Nozu, K., Dehejia, A., Zawistowich, L., Catt, K.J. \& Dufau, M.L. (1982) Gonadotropin-induced desensitization of Leydig cells in vivo and in vitro: estrogen action in the testis. Annls N.Y. Acad. Sci. 383, 212-229.

Pandey, K.N., Melner, M.H., Parmentier, M. \& Inagami, T. (1984) Demonstration of renin activity in purified rat Leydig cells: evidence for the existence of an endogenous inactive (latent) form of enzyme. Endocrinology 115, 1753-1759.

Parmentier, M., Inagami, T., Pochet, R. \& Desclin, J.C. (1983) Pituitary-dependent renin-like immunoreactivity in the rat testis. Endocrinology 112, 1318-1323.

Parvinen, M. (1982) Regulation of the seminiferous epithelium. Endocr. Rev. 3, 404 417.

Parvinen, M., Nikula, H. \& Huhtaniemi, I. (1984) Cyclic regulation of rat Leydig cell testosterone production by seminiferous tubules. Annls N.Y. Acad. Sci. 438, $681-683$.

Payne, A.H. \& Valladares, L.E. (1980) Regulation of testicular aromatization by luteinizing hormone. In Testicular Development, Structure and Function, pp. 185-193. Eds A. Steinberger \& E. Steinberger. Raven Press, New York.

Peake, G.T. \& Smoake, J.A. (1985) Regulation by calmodulin of adenylate cyclase activity in the anterior pituitary. Endocrinology 116, 2098-2102.

Purvis, K., Cusan, L. \& Hansson, V. (1981) Regulation of steroidogenesis and steroid action in Leydig cells. $J$. Steroid Biochem. 15, 77-86.

Quinn, P.G. \& Payne, A.H. (1985) Steroid productinduced, oxygen-mediated damage of microsomal cytochrome P-450 enzymes in Leydig cell cultures. $J$. biol. Chem. 260, 2092-2099.

Rajaniemi, H.J., Manninen, M. \& Huhtaniemi, I.T. (1979) Catabolism of human ${ }^{125}$ I iodochorionic gonadotropin in rat testis. Endocrinology 105, 1208-1214.

Rasmussen, H. (1980) Calcium and cAMP in stimulusresponse coupling. Ann. N.Y. Acad. Sci. 356, 346-353.

Reiter, E.O., Beitins, I.Z., Ostrea, T. \& Gutai, J.P. (1982) Bioassayable luteinizing hormone during childhood 
and adolescence and in patients with delayed pubertal development. J. clin. Endocr. Metab. 54, 155-161.

Ritzen, E.M., Hansson, V. \& French, F.S. (1981) The Sertoli cell. In The Testis, pp. 171-194. Eds H. Burger \& D. de Kretser. Raven Press, New York.

Rommerts, F.F.G., Hoogerbrugge, J.W. \& van der Molen, H.J. (1985) Stimulation of steroid production in isolated Leydig cells by unknown factors in testicular fluid differs from effects of luteinizing hormone or luteinizing hormone releasing hormone. Acta endocr., Copenh., Suppl. 270, 214, Abstr.

Rosness, P.A., Sunde, A. \& Eik-Nes, K.B. (1977) Production and effects of $7 \alpha$-hydroxytestosterone on testosterone and dihydrotestosterone metabolism in rat testis. Biochim. Biophys. Acta 488, 55-68.

Sanborn, B.M., Wagle, J.R. \& Steinberger, A. (1984) Maturational and androgen-dependent aspects of Sertoli cell function. Annls N.Y. Acad. Sci. 438, 586-587.

Sharpe, R.M. (1982) Cellular aspects of the inhibitory actions of LH-RH on the ovary and the testis. $J$. Reprod. Fert. 64, 517-527.

Sharpe, R.M. \& Bartlett, J.M.S. (1985) Stimulation of Leydig cell function by a polypeptide present in testicular interstitial fluid. Med. Biol. 63, 245-250.

Sharpe, R.M. \& Cooper, I. (1983) Testicular interstitial fluid as a monitor for changes in the intratesticular environment in the rat. $J$. Reprod. Fert. 69, 125-135.

Sharpe, R.M., Fraser, H.M., Cooper, I. \& Rommerts, F.F.G. (1982) The secretion, measurement and function of a testicular LHRH-like factor. Annls N.Y. Acad. Sci. 383, 272-292.

Sharpe, R.M., Doogan, D.G. \& Cooper, I. (1983) Direct effects of a luteinizing hormone-releasing hormone agonist on intratesticular levels of testosterone and interstitial fluid formation in intact male rats. Endocrinology 113, 1306-1313.

Shaw, M.J., Georgopoulos, L.E. \& Payne, A.H. (1979) Synergistic effect of follicle-stimulating hormone and luteinizing hormone on testicular $\Delta^{5}-3 \beta$-hydroxysteroid dehydrogenase-isomerase: application of a new method for separation and testicular compartments. Endocrinology 104, 912-918.

Shu-Dong, T., Phillips, D.M., Halmi, N., Krieger, D. \& Bardin, C.W. (1982) $\beta$-Endorphin is present in the male reproductive tract of five species. Biol. Reprod. 27, 755-764.

Stallings, M.H., Matt, K.S., Amador, A., Bartke, A., Siler-Khodr, T.M., Soares, M.J. \& Talamantes, F. (1985) Regulation of testicular $\mathrm{LH} / \mathrm{hCG}$ receptors in golden hamsters (Mesocricetus auratus) during development. J. Reprod. Fert. 75, 663-670.

Steinberger, E. (1971) Hormonal control of mammalian spermatogenesis. Physiol. Rev. 51, 1-22.

Syed, V., Khan, S.A. \& Ritzen, E.M. (1985) Stage specific inhibition of interstitial cell testosterone secretion by rat seminiferous tubules in vitro. Molec. cell. Endocrinol. 40, 257-264.

Tähkä, K.M. \& Rajaniemi, H. (1985) Photoperiodic modulation of testicular LH receptors in the bank vole (Clethrionomys glareolus). J. Reprod. Fert. 75, 513-519.

Tähkä, K.M., Teräväinen, T. \& Wallgren, H. (1982) Effect of photoperiod on the testicular steroidogenesis of the bank vole (Clethrionomys glareolus,
Schreber). An in vitro study. Gen. comp. Endocr. 47, 377-384.

Tähkä, K.M., Ruokonen, A., Wallgren, H. \& Teräväinen, T. (1983a) Temporal changes in testicular histology and steroidogenesis in juvenile bank voles (Clethrionomys glareolus, Schreber) subjected to different photoperiods. Endocrinology 112, 1420-1426.

Tähkä, K.M., Teräväinen, T. \& Wallgren, H. (1983b) Testicular steroid metabolism in juvenile bank voles (Clethrionomys glareolus, Schreber) exposed to different photoperiods. An in vitro study. Gen. comp. Endocr. 51, 394-400.

Terada, N., Sato, B. \& Matsumoto, K. (1980) Formation of $5 \beta$ - and $5 \alpha$-products as major $\mathrm{C}_{19}$ steroids from progesterone in vitro in immature golden hamster testes. Endocrinology 106, 1554-1561.

Teräväinen, T. \& Tähkä, K.M. (1985) Photoperiodinduced changes in the testicular metabolism of $\left[4-{ }^{14} \mathrm{C}\right] 17 \alpha$-hydroxyprogesterone in the bank vole (Clethrionomys glareolus). J. Reprod. Fert. 74, 625-630.

Themmen, A.P.N., Hoogerbrugge, J.W., Rommerts, F.F.G. \& van der Molen, H.J. (1985a) Is cAMP the obligatory second messenger in the action of lutropin on Leydig cell steroidogenesis? Biochem. Biophys. Res. Commun. 128, $1164-1172$.

Themmen, A.P.N., Hoogerbrugge, J.W., Rommerts, F.F.G. \& van der Molen, H.J. (1985b) The possible role of protein kinase $\mathrm{C}$ (PK-C) in lutropin (LH) action on immature rat Leydig cells. Acta endocr., Copenh., Suppl. 270, 207, Abstr.

Tsai-Morris, C., Aquilano, D.R. \& Dufau, M.L. (1985) Gonadotropic regulation of aromatase activity in the adult rat testis. Endocrinology 116, 31-37.

Tsang, B.K. \& Carnegie, J.A. (1983) Calcium requirement in the gonadotropic regulation of rat granulosa cell progesterone production. Endocrinology 113, 763-769.

Tsuji, M., Takeyama, M., Takatsuka, D., Yabumoto, H., Terada, N. \& Matsumoto, K. (1984) $5 \alpha$ - and $5 \beta$ reductases for 4-ene-3-ketosteroids and 17 -oldehydrogenase in epididymis and testis of golden hamster during sexual development. J. Steroid Biochem. 21, 179-183.

Veijola, M. \& Rajaniemi, H. (1985) Luteinizing hormones activate in testicular interstitial fluid a factor(s) that increases the capillary permeability - a novel effect of hCG and LH. Acta endocr., Copenh., Suppl. 270, 205, Abstr.

Verhoeven, G. \& Cailleau, J. (1985) A factor in spent media from Sertoli cell-enriched cultures that stimulates steroidogenesis in Leydig cells. Molec. cell. Endocrinol. 47, 57-68.

Warner, B., Dufau, M.L. \& Santen, R.J. (1984) Effect of age and illness on LH bio/immuno ratio. Annls N.Y. Acad. Sci. 438, 492-496.

Warren, D.W., Dufau, M.L. \& Catt, K.J. (1982) Hormonal regulation of gonadotropin receptors and steroidogenesis in cultured fetal rat testes. Science, N.Y. 218, 375-377.

Wartenberg, H. (1981) Differentiation and the development of the testes. In The Testis, pp. 39.80. Eds H. Burger \& D. de Kretser. Raven Press, New York.

Welsh, T.H., Jr \& Hsueh, A.J.W. (1982) Mechanism of the inhibitory action of epidermal growth factor on 
testicular androgen biosynthesis in vitro. Endocrinology 110, 1498-1506.

Welsh, T.H., Jr, Bambino, T.H. \& Hsueh, A.J. (1982) Mechanism of glucocorticoid-induced suppression of testicular androgen biosynthesis in vitro. Biol. Reprod. 27, 1138-1146.

Welsh, T.H. Jr, Jones, P.B.C. \& Hsueh, A.J.W. (1984) Phorbol ester inhibition of ovarian and testicular steroidogenesis in vitro. Cancer Res. 44, 885-892.
Wilton, L.J. \& de Kretser, D.M. (1984) The influence of luteinizing hormone on the Leydig cells of cryptorchid rat testes. Acta endocr., Copenh. 107, 110-116.

Yee, J.B. \& Hutson, J.C. (1985) Effects of testicular macrophage-conditioned medium on testosterone production by Leydig cells. Biol. Reprod. 32, Suppl. 1,45 , Abstr.

Received 3 January 1986 